\title{
Externalizing, internalizing and fostering commitment: the case of born-global firms in emerging economies
}

Article

Accepted Version

Glaister, A. J., Liu, Y., Sahadev, S. and Gomes, E. (2014) Externalizing, internalizing and fostering commitment: the case of born-global firms in emerging economies. Management International Review, 54 (4). pp. 473-496. ISSN 1861-8901 doi: https://doi.org/10.1007/s11575-014-0215-6 Available at https://centaur.reading.ac.uk/81626/

It is advisable to refer to the publisher's version if you intend to cite from the work. See Guidance on citing.

To link to this article DOI: http://dx.doi.org/10.1007/s11575-014-0215-6

Publisher: Springer

All outputs in CentAUR are protected by Intellectual Property Rights law, including copyright law. Copyright and IPR is retained by the creators or other copyright holders. Terms and conditions for use of this material are defined in the End User Agreement.

www.reading.ac.uk/centaur 
Central Archive at the University of Reading

Reading's research outputs online 
EXTERNALIZING, INTERNALIZING AND FOSTERING COMMITMENT: THE CASE OF BORN-GLOBAL FIRMS IN EMERGING ECONOMIES

\begin{abstract}
This paper examines the HR practices of mature born-global firms from twenty-nine emerging economies. Through an examination of large scale survey data the paper questions the extent to which firm size impacts the employment of temporary workers, the employment of skilled workers and the extent of employee training. Findings suggest that as firm size increases the use of temporary workers decreases, the number of skilled workers increases and the number of employees receiving training also increases. The paper highlights how born-global firms are able to shift away from externalized, market-based approaches towards more internalized, commitment-based approaches in order to survive, adapt and grow.
\end{abstract}

Keywords: mature-born global firms, skilled labour, temporary workers, training levels, emerging economies, human resource management, networks. 


\section{Introduction}

The last two decades have witnessed an unparalleled growth in the number of SMEs that internationalize from an early stage of their operations. These firms have been referred to as 'born global' (BG) because of their early and rapid internationalization and are commonly characterized as young, knowledge-intensive organizations that sell mainly innovative, selfdeveloped technology-based products (Almor 2013; Almor 2011; Aspelund and Moen 2012; Knight and Cavusgil 2004; Li et al. 2012). BGs are therefore defined as firms that almost from inception seek superior international business performance from the application of (knowledge-based) resources to the sale of outputs in multiple countries (Knight and Cavusgil 2004; Gabrielsson et al. 2008).

The rapid growth of these firms has been accompanied by a corresponding increase in research, with scholars examining the characteristics of BGs and their entrepreneurs (Evangelista 2005; Kalinic and Forza 2012; Odorici and Presutti 2013; Rasmussen et al. 2012; Spence et al. 2011), the challenges they face in their channel selection (Gabrielsson and Gabrielsson 2011; Gabrielsson and Kirpalani 2004), the role of knowledge in the internationalisation process (Gassmann and Keupp 2007; Nordman and Melén 2008; Presutti et al. 2007), the reasons why BGs are able to internationalize so quickly and from an early stage (Rialp et al. 2005; Taylor and Jack 2013; Zou and Ghauri 2010), the relationship between entry mode patterns and competitive advantage (J. Zhang and Dai 2013; Gassmann and Keupp 2007), the impact of financial management on BGs (Gabrielsson et al. 2004), the role of trust and contracts (Blomqvist et al. 2008) and the important roles played by marketing and IT functions (M. Zhang et al. 2013; Evers et al. 2012). As this body of knowledge consolidates it is important to understand how mature BGs succeed and the practices that underpin their long-term growth. In this context the human resource management practices employed by mature BG firms remain under-researched. 
The study seeks to fill this important gap and considers key HR practices including the use of contingent labour, the recruitment of skilled labour, and the extent of employee training. While these selected practices do not embody a comprehensive set of HRM practices, they have been examined in several prior studies to evaluate HRM in MNEs (Edwards et al. 2010; Tregaskis and Brewster 2006; Sahadev and Demirbag 2011).

This paper is innovative in several ways: It is the first to focus on mature BGs operating in an emerging market context. Our particular interest in mature BGs is novel and is justified by the fact that the prior literature on the topic provides insights only into the international behaviour and characteristics of traditionally known born global firms. Second, the paper is unique in its examination of HRM practices utilised by mature BGs and in particular makes a strong case for the need for incumbent BG managers to design and implement an effective training policy in line with their growth needs.

The paper is structured as follows: First, the theoretical background underpinning this study is discussed and hypotheses are developed. This is followed by an examination of the research methods and data analysis techniques employed. The results of the study are then presented and the main findings discussed. The concluding section discusses the theoretical and managerial implications of the study and proposes avenues for further research.

\section{Theoretical Background and Hypotheses Development}

\section{$\underline{\text { Knowledge-based view and born global firms }}$}

The knowledge-based view regards firms as knowledge generators and integrators (Grant 1996; Kogut and Zander 1992). A firm's ability to create value hinges largely on sets of intangible, knowledge-based resources (Leonard 1998; Nonaka 1994). Firms can generate higher than average performance if they possess value-creating organizational knowledge 
which is relatively rare or idiosyncratic and difficult to substitute. The knowledge-based view has been used to examine the internationalization of smaller born-global firms (Autio 2005; Johanson and Vahlne 2006; Park and Rhee 2012). Essentially, the resources of a small and medium-sized enterprise (SME) can be reduced to knowledge as the single intangible resource (Chetty and Wilson 2003; Gassmann and Keupp 2007). Nordman and Melén (2008) distinguished two types of knowledge pertinent to a firm's internationalization, namely international knowledge and technological knowledge. BGs rely greatly on technological knowledge to develop their internationalization activities (Efrat and Shoham 2011; Kim et al. 2011; Li et al. 2012). Building upon this argument, one recent study found that BGs tend to internationalize rapidly into markets which are ready to adopt their technology (Freeman et al. 2012). Consequently, they usually seek culturally proximate markets to exploit economies of scale and to establish a revenue stream as quickly as possible. BG managers can use both preexisting and newly formed relationships to quickly and proactively develop new knowledge for rapid commercialization of their products (Freeman et al. 2010).

One distinctive feature of BGs is their rapid internationalization process (Hashai and Almor 2004; Hewerdine and Welch 2013; Wickramasekera and Oczkowski 2006). The knowledgebased view can play a crucial role in explaining this important feature. Almor and Hashai (2004) demonstrate that BGs still exhibit sequential internationalization, but at a faster pace than the Uppsala model predicts (Johanson and Vahlne 2006). BGs use more complex foreign market servicing modes, internationalize different activities, and enter psychically distant markets (Almor and Hashai 2004). The accumulated knowledge base associated with foreign experience helps to explain the internationalization route of BGs. Hashai (2011) argues that BG firms stick to one dominant internationalization path, either expanding geographic scope or intensifying the extent of their foreign operations. We argue that knowledge accrual has an important bearing on the chosen internationalization path. 
Knowledge is considered central to the internationalization of BGs. Upon entering foreign markets BGs may recognize that the knowledge they possess does not meet the knowledge needed for successfully operating the foreign business venture. BGs perceive more procedural barriers during their ventures and struggle to communicate with their foreign customers and require financial, technological and marketing support from partners that often fails to transpire (Hewerdine and Welch 2013; Uner et al. 2013). Evers et al; (2012) suggest that BGs develop regenerative capabilities by leveraging competencies both inside and outside the organization, and that these capabilities are developed through employee engagement. Thus, we argue that it is through leveraging HRM practices that BGs are able to develop the knowledge needed for successful market penetration. The next section discusses the importance of the organization's HR architecture.

\section{$\underline{\text { Selecting the HR Architecture }}$}

BGs rely extensively on a range of networks which provide the skills and expertise to help build and sustain legitimacy within the competitive environment (Evers et al. 2012; Ojala and Heikkilä 2011; Sepulveda and Gabrielsson 2013; Smith et al. 2012). Vasilchenko and Morrish (2011) suggest that BGs utilise social and business network forms. The former influences market selection while the latter is central in gaining credibility in new markets. During the early stages of development, BGs adopt a more utilitarian approach to their networks and use them to secure funding, product knowledge, expertise and support for their international expansion (Sepulveda and Gabrielsson 2013:7). However, over time, BGs focus on reducing their external resource dependence and develop new internal competencies and enhanced branding and reputation. It is this new internal knowledge development that enables BGs to use their networks in more strategic ways. According to Sepulveda and Gabrielsson (2013), BGs reach a point where these network relationships hinder further development and expansion, and the more a BG develops its internal resources, the more choice it has over how it balances externalization and internalization decisions. At this latter point, BGs' skill 
requirements become more specialist in nature (Ojala and Heikkilä 2011), thus prompting the internal development of resources to establish a reputation and accumulate operational knowledge in order to engage in areas that were previously beyond their internal resource capacity (Coviello and Cox 2006; Hite and Hesterly 2001; Gabrielsson et al. 2008). The emphasis is placed on human capital: talent attraction, retention and employee flexibility (Karra et al. 2008).

The initial dependence on networks and the gradual shift to more internalization suggests a need for BGs to focus on developing an appropriate HR architecture. Lepak and Snell (1999) identify four key HR approaches according to the value and the uniqueness of human capital. Each requires an externalized or internalized employment mode and a corresponding relational or transactional employment relationship. Core employees possess knowledge that is specific to the firm and central to organizational competitiveness. These are internalized and a range of commitment-based HR practices support a relational employment relationship. On the other hand, traditional employees possess knowledge that is not unique, is easily transferrable but still has strategic value. These individuals are also internalized but the corresponding HR approaches tend to be more transactional and productivity-based in nature. External alliance partners possess knowledge that is particularly unique but not instrumental in creating customer value, as a result they are externalized but their unique knowledge requires more relational approaches to HR practice. In contrast, contract workers possess knowledge that is neither unique nor of particular value, therefore supporting a more transactional externalized approach. These four HR configurations can exist within one organization and each contributes to strategy in different ways (Kang et al. 2007).

Knowledge intensive firms (KIFs) which include BGs, need to constantly update their skills. Network interaction provides the opportunity to achieve skill renewal and helps to manage the stock and flow of knowledge (Kang et al. 2007). This creates an intensely changeable and precarious work environment where knowledge has more power than position (Alvesson 
2004). However, as the boundaries of the firm become increasingly permeable (Swart and Harvey 2011; Swart and Kinnie 2003a) so does the mobility of the workforce as "personnel changes and purchase of capital goods generally offer fast ways to pick up new ideas" (Starbuck 1992:736). In this environment the knowledge possessed by people is central to the competitive positioning of the firm (Karra et al. 2008; Robertson and Swan 2003) but this knowledge is easily lost through network reliance and the acceptance of more contingent forms of labour. Staff turnover causes the leakage of core knowledge and organizations become vulnerable to the loss of corporate memory, tacit knowledge and their customer base (Daghfous et al. 2013; Durst and Wilhelm 2011; Martins and Meyer 2012). This places a premium on developing human capital and the HR systems that are used to foster employee loyalty and commitment (Andreeva and Kianto 2012; Joe et al. 2013; Lepak and Snell 2008).

\section{The Importance of Size}

Firm size is an important variable affecting organizational behaviour. Scholars suggest that size plays an important role in affecting HRM practices. For instance, firm size might mitigate national cultural effects on HRM practices by virtue of internal organizational cultures (Ryan et al. 1999). Larger firms tend to form standardized HRM practices (Dimaggio and Powell 1983; Gooderham et al. 1999). With respect to resources, larger firms are likely to possess more resources to establish and coordinate internationally dispersed activities than small firms, enabling them to develop global brand names and exploit economies of scale and scope. Thus, firm size may enable international expansion and international success (Almor 2011).

The mature BG can be viewed as one which has passed the survival threshold with the total number of employees commonly used as a measure of size in studying BGs (Hashai and Almor 2004). We subscribe to this approach as it provides several advantages in investigating BGs and their HRM investments: Firstly, employee composition indicates the knowledge structure of firms within and beyond organizational boundaries. Secondly, the knowledge 
base differs between the founders and recruited employees. Initially knowledge resides within the entrepreneurs but as the BG grows this knowledge becomes increasingly varied and dispersed. Thirdly, internalization and externalization will impact the nature and extent of knowledge accumulation and the need remains for BGs to balance the risks inherent in each approach.

The next section develops the key hypotheses of the paper through an examination of three key HRM practices that are considered central to BG firms, these are: the use of temporary labour, the recruitment of skilled labour and the extent of training coverage.

\section{$\underline{\text { Temporary workers }}$}

The use of flexible and temporary forms of employment enables firms to withstand the increasing pressures for lower costs and uncertainty in international markets (Brewster et al. 1997; De Cuyper and De Witte 2007; Kalleberg 2000). As Tregaskis and Brewster (2006) suggest, organizations are more likely to employ temporary workers in order to remain competitive since these workers provide numerical flexibility without the ongoing costs. Initially, as a risk reduction measure, BGs may recruit more temporary workers (Weerawardena et al. 2007) and professional service providers will be able to offer the skills and knowledge needed to mitigate any risk. However, BGs might experience a problem in the supply of temporary labour, and the delays in recruiting can stymie the growth of the firm. (Gilbert et al. 2006). As BGs mature, they need to develop a greater commitment to develop market specific capabilities, integrating market knowledge with organizational knowledge in

order to maintain firm specific advantage (Freeman et al. 2006; Khalid and Larimo 2012; Mathews and Zander 2007). Research examining serial international entrepreneurs suggests that BGs need to foster human capital in each country where they are active (Karra et al. 2008), and as the knowledge derived from contingent labour becomes codified and 
internalized, the best way to retain key knowledge is to provide long-term stability through permanent work (Freeman et al. 2010). This leads to the following hypothesis:

Hypothesis 1: As the size of mature BG firms increases, BG reliance on temporary workers will decrease.

\section{The Recruitment of Skilled Labour}

As acknowledged in prior studies, a skilled labour force is considered to be an important factor enhancing firm capability and international competitiveness (Sahadev and Demirbag 2011, 2010; Karamessini 2008). According to Sahadev and Demirbag (2011), the increase in the percentage of a skilled labour force has been mostly enabled through intensive investment in $\mathrm{R} \& \mathrm{D}$ and, more especially, through mechanisms of technology and knowledge transfer across countries. As noted, mature BGs might enlarge their geographic scope or intensify the extent of foreign operations (Hashai 2011). Skilled workers play an important role in either one of these internationalization paths and the level of sophistication in BG operations will increase as they mature.

The presence of value-adding activities such as $\mathrm{R} \& \mathrm{D}$, production and marketing activities are more likely to be observed in mature BGs (Almor et al. 2006). There exists a commensurate need to recruit skilled workers to apply their knowledge to these value-adding activities; whether in a greenfield or merger and acquisition situation (Hashai and Almor 2004). This knowledge will enable BGs to pursue expedient growth strategies. Therefore, it can be assumed that the need to recruit and retain skilled labour in mature BGs is much higher than non-mature BGs. This leads to the following hypothesis:

Hypothesis 2: As their size increases mature born global firms will employ greater numbers of skilled labour. 
Training

Firm capabilities, including market knowledge and technology capabilities, are crucial to BG survival and success over the long term (Zhang et al. 2013; Efrat and Shoham 2012). Institutional and cultural differences inherent within BG activities suggest a need to develop and equip employees with the skill to be able to handle cross-border tasks (Aycan 2005). Professionals working within the BG are expected to stay at the forefront of knowledge, therefore the provision of a suitable learning climate and the development of knowledge is key to innovation and profitability and vital in an environment which relies upon shared understanding (Alvesson 2004; Fong et al. 2011; Shipton et al. 2005; Swart and Kinnie 2003b). Khalid and Larimo (2012:247) suggest BGs from emerging markets might focus on building market based knowledge and innovative capabilities to aid international expansion, but will be in competition with BGs from developed markets who will invest in learning in order to increase the effectiveness of organizational and market knowledge. Khalid and Larimo (2012) do not distinguish between new and mature BGs, however mature BGs will face similar pressures and may seek to differentiate themselves through employee-focussed practices.

The investment in training opportunities is particularly important where professional groups identify with their profession rather than the employing organization (Alvesson 2000; Swart 2008). According to Swart (2008), this lack of organizational identity may lead to outward flows of knowledge and therefore training within this context may influence a sense of reciprocity, demonstrate commitment to the individual and "stimulate depurification of professional orientations" (Alvesson 2004:146). Training also enables the creation of what Starbuck $(1992: 724,730)$ terms "dynamic stability" where knowledge evolves while experts are able to retain their favourable position within the organization, balancing the need for "fluidity and ambiguity" while erecting "mobility barriers" through a suitable organizational culture (Swart 2008:9). 
The BG's provision of training and formalized HR policies will be influenced by institutional requirements (Sahadev and Demirbag 2011) and the size of the firm. Aycan (2005) asserts that larger firms may be able to invest in more training and development activities than smaller firms because larger firms can access and leverage more resources. Early stage BGs tend to rely on the knowledge of their founder entrepreneurs and the extent of their international experience. This might not be sufficient for a growing and maturing BG as a rapid growth trajectory requires the need to accumulate and disseminate international knowledge beyond the entrepreneur's knowledge base (Fernhaber et al. 2009). BGs will therefore incrementally increase HRM investment in training as their size increases. This is consistent with Aycan (2005) who argues that organizational size is amongst the most important contingencies influencing training and developmental activities and Quester and Kelly (1999) who suggest that large organizations tend to provide more training . This leads to the following hypothesis:

Hypothesis 3: As the size of the mature BG increases, the extent of training coverage also increases.

\section{Research Methods}

The hypotheses were tested through data collected by the World Bank's enterprise survey project (http://www.enterprisesurveys.org). The enterprise survey project is unique in its global coverage and is a large scale data gathering project conducted through a well-trained network of professionals across more than 100 countries. Data is gathered on firm size, business sector and geographic region within a country. A stratified sampling methodology is adopted ensuring greater representation and generalizability when compared to convenience sampling or simple random sampling. The survey is completed by business owners and top managers of the surveyed organizations. Only private enterprises are included in the sample 
and respondents are promised full confidentiality, encouraging the provision of accurate information (http://www.enterprisesurveys.org). Data from the enterprise survey project has been used widely in prior academic research because of its global scope, standardized questionnaire and extensive coverage (cf. Bardasi et al. 2011; Jensen et al. 2010; Sahadev and Demirbag 2011).

The sample frame used for the survey consists of eligible firms listed in the country's statistical office and those drawn from a master list of firms registered with government agencies, including tax and business licencing authorities. Due to the prestige and resources of the World Bank, it is possible to construct a sample frame that is as exhaustive and comprehensive as possible. From 2005-06 surveys include documentation explaining the source of the sample frame and any special circumstances encountered during the survey fieldwork.

Though the enterprise data is drawn from a large cross section of countries, it is pertinent to note that all the countries in our sample are emerging economies and we have introduced two country level variables (Infrastructural development index and Institutional development index) that are able to capture any country level variation, and studies support the pooling of data from countries at the same level of economic development (cf. Blonigen and Wang 2004).

This study is based on data collected through the enterprise survey project between 2006 and 2010. Data collected using the standard questionnaire was first aggregated and only firms which could be considered as BG were retained. This required calculating the time difference between the year the firm was founded and the year the firm started exporting (Knight et al. 2004). In line with Knight et al. (2004) and Nordman and Melén (2008) only those firms that 
started exporting within the first three years of their incorporation were retained in the database.

In the next step, firms with unusually high values for the independent variables of interest such as export levels of more than $100 \%$, and employee size of more than 100,000 were deleted. Similarly firms with missing values for all the dependent variables were also deleted. Since the focus of the research is on mature BG enterprises, only firms which were at least 10 years or older were considered for the analysis. Some studies investigating the influence of firm age on growth demonstrate that variability in growth fluctuates with firm age (Das 1995; Evans 1987; Mata and Portugal 1994). Though some scholars (e.g. Bantel 1998) suggest that firms only reach a more mature phase after 12 years, Das's (1995) findings show that firms tend to register a more significant variation in average size and reach a more mature stage between 10 and 11 years. A total of 890 firms from 29 different countries were included in the final database. Table 1 shows the sample profile in terms of the country of origin of the firms and the average age of firms from each country. As the table shows, most of the companies were from emerging economies.

Take in Table 1 here

$\underline{\text { Variables }}$

The variables considered were either directly drawn from the enterprise survey database or calculated using simple mathematical transformation from the original variables provided in the database. The dependent variables: (i) temporary worker ratio (ii) skilled worker ratio and (iii) training levels were all ratios calculated from the original variable list. The temporary worker ratio was calculated by dividing the number of full-time temporary employees with 
the number of full-time permanent employees the firm had employed in the year preceding the survey distribution. The skilled worker ratio was calculated by dividing the number of full time employees who were skilled to the number of full time employees. The training level was calculated as a ratio of the total number of employees (both production and nonproduction) who received training to the total number of employees of the firm.

\section{$\underline{\text { Control Variables }}$}

The impact of firm size on HRM practices is tested in relation to two main types of control variables: firm level factors and host country macro factors. Several firm level factors are likely to have an effect on international HRM practices factors (Bhandari and Heshmati 2006; Sahadev and Demirbag 2011; Thite et al. 2012). The firm level variables used are: i) Number of years of operation of the firm, ii) Sector in which the firm operates, iii) Level of foreign investment in the firm and iv) Percentage of foreign sales.

Prior studies have included firm age as a control variable and found it to have an important influence on HRM practices (Holtbrügge et al. 2010; Sahadev and Demirbag 2010; Wright et al. 2001). According to Holtbrügge et al. (2010:449), firm age is important because "HRM practices are path-dependent; that is, the spectrum of alternatives at a given moment in time depends on the decisions made in the past". As such, considering age when analysing the international HRM practices of BGs is important because their HRM practices may evolve as they gain more international experience over time.

Sahadev and Demirbag's (2011) research findings demonstrate that industry sector strongly influences international contingent employment practices. Thite et al; (2012) assert that this is particularly significant in the case of emerging markets where firms from different sectors tend to adopt different employment practices. Bhandari and Heshmati's (2006) findings show that the incidents of temporary versus permanent work in Indian firms varied across industries. 
Several scholars have found levels of foreign ownership to be associated with international HRM practices (Bhaumik et al., 2010; Hsu and Leat 2000), providing firms with international experience and managerial and technological know-how (Lu et al., 2011) that are vital in helping them overcome the liability of 'foreignness' when expanding abroad (Jormanainen and Koveshnikov 2012). Equally when venture capitalists invest in BGs they provide knowledge through their professional network and experience (Fernhaber et al. 2009).

The percentage of foreign sales is also an important factor in defining BGs and measuring their 'born-globalness' (Kuivalainen et al. 2007), as BGs increase their percentage of foreign sales at a faster rate than local small and medium-sized enterprises (Jones 2001). Firm sales have been used as a control variable for firm size in previous studies (Hashai 2011) and higher levels of foreign sales are associated with higher levels of international experience (Efrat and Shoham 2012; Johanson and Vahlne 2006). Hence, percentage of foreign sales is selected as a suitable control variable for BG firms. To summarize: the size of the firms was calculated as the logarithm of the total number of employees of the firm. The firm level control variables used included export orientation, percentage of foreign capital, age of the firm as well as the sector in which the firm operated. The firm sector was operationalized as a dummy variable with ten sectors. Export orientation was calculated as the percentage of sales of the firm earned through exports.

Consistent with previous studies, we use host country macro level factors as these are likely to have an effect on the firm's international HRM practices (Bae et al. 1998; Sahadev and Demirbag 2011, 2010). For example, the positive performance of the Israeli economy amidst the recent global recession might be attributed to the success of their high-tech born-global firms (Almor 2011), yet it is acknowledged that macro level factors such as market growth and country risk affect the survival and performance of BGs (Efrat and Shoham 2012). The 
use of macro level factors as control variables becomes particularly important because all BGs included in the sample are from emerging markets.

In line with several authors, we define emerging markets as those markets that, despite the persistence of fragile and unstable macro institutional systems, have been growing significantly in recent years as a result of major industrial structural changes (Jormanainen and Koveshnikov 2012; Luo and Tung 2007; Hoskisson et al. 2013). Therefore, we use two key institutional level factors suggested by Hoskisson et al; (2013): i) Institutional development index of the country operation, and ii) Infrastructural development index of the country of operation. As a typology, with a focus on mid-range emerging economies, institutional development means the development of market-supporting political, legal and economic institutions; the infrastructural development index indicates the infrastructure and factor market development. In line with Hoskisson et al. (2013), we use the World Economic Forum's Global Competitiveness Report 2011-12 (GCR) (Schwab 2011) in operationalizing these two variables. Institutional development is measured by the score in the GCR. Infrastructure and factor market development are operationalized by summing and averaging the Infrastructure, Macroeconomic environment and Health \& Education measures in the GCR into one measure. This index is calculated for each country based on a global export opinion survey. The correlation coefficients of the variables are given in Table 2.

Take in Table 2 here

\section{Data Analysis}

In order to examine the impact of size of mature BGs on HR related variables a series of regression analyses were carried out. In the first regression equation, the effect of size of the firm on the temporary worker ratio was assessed. The multi-collinearity diagnostics were within acceptable levels with the VIF values of the continuous variables less than 3.00. The 
overall validity of the model expressed in terms of the $\mathrm{R}^{2}$ value and F-value were also within acceptable levels. The results of this analysis are shown in Table 3.

Take in Table 3 here

As the results show, there is a significant negative relationship between the size of the firm and the level of employment of temporary workers. This supports hypothesis 1 - as the size of the BG firm increases, the use of temporary workers decreases. Equally, among the control variables export orientation, foreign investment level and the age of the firm all have positive significant coefficients (at $\mathrm{p}<0.1)$ level. This indicates that temporary employment levels are positively impacted by the export dependence of the firm, the extent of foreign investment as well as the age of the firm. Older firms tend to be employing more temporary workers and highly export dependent firms also employ more temporary workers. Infrastructural development of the country of operation of the firm tends to negatively influence the employment of temporary workers. Thus, if infrastructural development is low, more temporary workers are employed. There is no relationship between the level of institutional development of the country within which the firm operates and the employment of temporary workers. The level of employment of temporary workers also tends to be highly influenced by the industry sector. Almost all the sectors tend to employ temporary workers except for nonmetallic and plastic components and other manufacturing.

In the second regression equation, the impact of firm size was assessed against the amount of skilled workers employed. The skilled worker ratio of a firm was calculated as the number of skilled workers employed by the firm to the total number of full-time permanent workers. The multi-collinearity statistics were found to be within acceptable levels (VIF $<2.00$ for continuous variables), thereby establishing the validity of the results. The overall validity of the model measured in terms of $\mathrm{R}^{2}$ value and F-value were also within acceptable levels. Table 4 shows the results of the regression analysis. 
Take in Table 4 here

As Table 4 shows, the size of the firm has a positive impact on the level of skilled labour employed in the firm. In support of hypothesis 2, as firm size increases, mature BGs tend to employ more skilled labour. Amongst the control variables, export orientation also has a positive impact. This implies that the more the BG depends on the foreign market for its sales, the higher the proportion of skilled labour. Of the country level control variables, both the institutional development index and infrastructural development index do not appear to have any significant impact. In terms of organizational sector, both the food sector and manufacturing sector are the only ones that have a significant negative impact on the proportion of skilled labour, implying that these sectors tend to employ less skilled labour.

The final regression analysis tested the influence of BG size on the extent of training coverage. Training levels were measured as the ratio of the total number of employees trained to the total number of employees of the firm. Multi-collinearity statistics were within the acceptable levels for the analysis thereby establishing the validity of results. The overall validity of the analysis ( $\mathrm{R}^{2}$ and F-values) was adequate. The results are shown in Table 5.

Take in Table 5 here

As the results show, the size of the firm has a positive impact on the percentage of employees trained by the firm. This would imply that as the size of mature BGs increases so does their use of training, therefore hypotheses 3 is supported. None of the firm level control variables have a significant coefficient, though the level of institutional development of the country in which the BG operates has a significant negative coefficient. This implies that mature BGs operating in countries with lower levels of institutional development tend to train their employees more. The training levels seem to be heavily influenced by the sector in which the firms operate: Textiles/leather, Garments, Food, Metals and Machinery, Wood/furniture, Auto 
Components and Other Manufacturing all have significant negative coefficients indicating a reduced level of emphasis on employee training in these industry sectors.

\section{Discussion and Conclusion}

This paper adds value to our understanding of mature BGs in emerging market economies and is the first to examine HRM practices within this context. The paper makes a strong case of the need for incumbent BG managers to design and implement an effective training policy in line with their growth needs. Through an analysis of the mature BGs' recruitment of skilled labour, the use of contingent labour and training, the results from the regression analysis provide support for the hypotheses developed in this paper. Findings show that as the size of the mature BG increases, their reliance on temporary workers decreases; the number of skilled workers employed increases; and the level of training in the firm also increases. Firm level and country level control variables were also included in the analysis.

The findings are consistent with Lepak and Snell's (1999) HR architecture which suggests that the specific nature and importance of knowledge residing in core employees results in greater internalization and a relational employment mode which emphasizes commitmentbased HR practices, shown in this study through a reduction of contingent labour, an increase in skilled labour and an increase in training levels. While these findings are attributed to the size of the BG it would seem that even though several HR architect types can exist within one organization, it is the lifecycle stage and depth of market penetration of the organization that plays a key role in determining the nature of HR architecture employed. This helps to explain the findings that older BG firms rely on temporary workers and those firms that are export dependent recruit more contingent labour and employ more skilled individuals. 
While Starbuck (1992) suggests that KIFs leach knowledge intensity as they grow and tend to add support staff rather than experts, the findings of this study suggest that mature BGs seek skill renewal through training investment in order to respond to market pressures and strengthen their ties with their customers. This provides some support for Contractor and colleagues' perceived link between the foreign expertise of BG employees and BG firm performance (Contractor et al. 2005). While the data does not make it possible to identify either the recipients of these training interventions or the nature of the training provided, the employment of a greater degree of skilled labour suggests that training is being offered to skilled individuals, potentially creating redundant skill capacity, providing more opportunity for innovation and market responsiveness and enabling the market and organizational knowledge integration considered central to the creation of firm specific advantage (Khalid and Larimo 2012). In this case, training provision and internalization ensures a greater degree of organizational knowledge ownership and ties the worker to the organization through an understanding that their own professional network is nurtured through organizational resources. This would imply the implementation of a more sophisticated HR architecture of which recruitment and selection and training practices may only be a small part.

Overall, the findings support a shift away from external network reliance towards the development of internal resource capability at a specific point in the BG's lifecycle (Ojala and Heikkilä 2011; Sepulveda and Gabrielsson 2013). As firms grow in complexity, so too do their HR systems and the traditional 'control' strategy, which might include the more strategic use of remuneration packages to smooth more transactional relationships, is replaced gradually by commitment strategies aimed at aligning individual and organizational goals. However, there is contention over whether high commitment strategies necessarily offer high levels of innovation or whether innovation should be sustained through more transactional based market activity (Miles and Snow 1984; Schuler and Jackson 1987) and research suggests the former (Jiménez-Jiménez and Sanz-Valle 2005). However, as borne out by the findings, emerging markets may not have the infrastructure to support the appetite for the 
constant renewal of skills sought through the contingent labour market. In this instance it might be easier to foster organizational commitment through employment security and personal development, rather than relying on short term transactional exchanges which limit the investment in a more training-focussed approach.

Zhou et al (2013:279) suggest that there has to be a "punctuated equilibrium" between internal commitment and more collaborative/externalized approaches - only with resource slack can commitment-based and collaborative-based approaches co-exist. This might be true as BGs mature - they are able to balance the needs of their internal core with those of their external experts without damaging their organizational culture. Findings of the study suggest that this is the case with more mature BGs relying on externalized labour and recruiting more skilled labour. This supports Sepulveda and Gabrielsson's (2013) argument that the more established the BG the more it will use its network in instrumental ways and develop 'radical innovative capability' (Subramaniam and Youndt 2005) through a combination of human capital (individual employee capabilities) and social capital (leveraging the resources located in their network) (Lepak and Snell 2008).

The heterogeneity introduced into the workforce by temporary employees within larger BGs can undermine distinct organizational cultures (Loane et al. 2007). Since their inception BGs rely on a network of providers and more precarious forms of labour, therefore, distinct organizational cultures take time to develop. Training interventions combined with a reduced reliance upon contingent workers helps to mitigate this danger and foster a greater degree of organizational learning. The provision of training and the recruitment and selection of skilled labour suggests that larger BGs are able to gain knowledge advantage at the same time as developing a strong sense of organizational commitment. High-commitment HR practices provide symbolic value not only to those inside the organization, but to those outside as well. These practices help cement the competitive positioning of the firm and its reputation amongst its clients. 
The study's findings highlight that through a series of high commitment practices including the internalization of labour and the reduction of contingent labour, the increased selection of a skilled workforce and a greater emphasis on training, BGs are able to survive, adapt and grow. The shift from externalization towards internalization is particularly pertinent as it highlights the limitations of market-based approaches in eliciting a loyal and committed workforce and the need to shift towards high commitment work practices as BG firms grow in size. There is evidence of a skills 'lifecycle' - first, a commitment to externalization, second a shift towards greater internalization and, as firms mature, a more strategic balance between internalization and externalization.

These findings are particularly useful to practitioners and policy makers. First, the findings highlight the need for a dynamic HR architecture within BG firms and the design of an HR system that can respond to and pre-empt the strategic environment. A strong case is made for an emphasis to be placed on designing effective training policies that are specific to particular markets. As BGs grow, they need to develop their talent pipeline as a means of improving performance and buffering environmental uncertainty. This implies the need for dedicated HR expertise from the outset, which may run counter to the entrepreneurship inherent within new BG firms. By accessing dedicated HR expertise the BG will be able to design an appropriate HR system. This HR system should be flexible to the lifecycle needs of the organization and negotiate the difficult balance between losing network contacts through internalization during the second phase of the HR lifecycle, and rekindling these contacts during the third phase once enough knowledge has been accrued internally and a more strategic and instrumental approach to network leverage can be developed.

Second, policy makers need to be aware that entrepreneurial firms require institutional support and that without the supply of highly skilled individuals certain locations may not be able to cater for BG firms during the phase where collaboration and internalization are 
working as complements. Such BG firms will take their business elsewhere. Those emerging economies which actively promote export orientation need to be mindful of the ways in which BG firms require flexibility and a level of institutional support and regulation that does not impinge upon this flexibility but still provides a supportive environment that encourages broader knowledge sharing and fosters commitment-based practices within the BG's network.

\section{Limitations and Suggestions for Further Research}

A limitation of the study is the reliance on secondary data which does not make it possible to observe the extent of the bundle of high-commitment work practices used by BGs. Indeed, it would be useful for future research to examine primary data in order to evaluate whether there are any consistencies between BGs and their HR architectures and to compare the HRM practices of emerging market BGs to those of more mature economies. Further, the data does not allow a full insight into the nature of the HR architecture and how relations are established between providers and internal employees. This implies that BGs should be examined closely through primary data collection. Indeed, it would be useful for further studies to examine how the flows of knowledge are managed as BG firms mature, the extent to which knowledge can be shared across the network and the HR practices and processes that are employed to ensure knowledge growth and sharing. Questions are raised as to the extent to which this balanced approach impacts knowledge ownership and whether or not the implementation of high commitment work practices actually results in reduced staff turnover and mutual knowledge ownership between the worker and the organization. Nevertheless, it is clear that despite these limitations, the study makes a new and significant contribution to our understanding of the dynamic nature of important aspects of BGs' HR architecture.

\section{Acknowledgements}

The authors would like to thank Keith Glaister for his helpful comments on an earlier draft. 


\section{References}

Almor, T. (2013). Conceptualizing paths of growth for the technology-based, bornglobal firm originating in a small population, advanced economy. International Studies of Management \& Organization, 43(2), 56-78.

Almor, T. (2011). Dancing as fast as they can: Israeli high - tech firms and the Great Recession of 2008. Thunderbird International Business Review, 53(2), 195208.

Almor, T., \& Hashai, N. (2004). The competitive advantage and strategic configuration of knowledge-intensive, small-and medium-sized multinationals: a modified resource-based view. Journal of International Management, 10(4), 479-500.

Almor, T., Hashai, N., \& Hirsch, S. (2006). The product cycle revisited: Knowledge intensity and firm internationalization. Management International Review, 46(5), 507-528.

Alvesson, M. (2000). Social Indentity And The Problem of Loyalty In Knowledge Intensive Companies. Journal of Management Studies, 37(8), 1101-1124.

Alvesson, M. (2004). Knowledge work and knowledge-intensive firms. Oxford: Oxford University Press.

Andreeva, T., \& Kianto, A. (2012). Does knowledge management really matter? Linking knowledge management practices, competitiveness and economic performance. Journal of Knowledge Management, 16(4), 617-636.

Aspelund, A., \& Moen, C. (2012). International new ventures and governance structures - are international entrepreneurs strategic or entrepreneurial? Journal of Management \& Governance, 16(1), 125-146.

Autio, E. (2005). Creative tension: the significance of Ben Oviatt's and Patricia McDougall's article 'toward a theory of international new ventures'. Journal of International Business Studies, 36(1), 9-19.

Aycan, Z. (2005). The interplay between cultural and institutional/structural contingencies in human resource management practices. The International Journal of Human Resource Management, 16(7), 1083-1119.

Bae, J., Chen, S.-j., \& Lawler, J. J. (1998). Variations in human resource management in Asian countries: MNC home-country and host-country effects. International Journal of Human Resource Management, 9(4), 653-670.

Bantel, K. A. (1998). Technology-based,“adolescent” firm configurations: strategy identification, context, and performance. Journal of Business Venturing, 13(3), 205-230.

Bardasi, E., Sabarwal, S., \& Terrell, K. (2011). How do female entrepreneurs perform? Evidence from three developing regions. Small Business Economics, 37(4), 417-441.

Bhandari, A. K., \& Heshmati, A. (2006). Wage inequality and job insecurity among permanent and contract workers in India: evidence from organized manufacturing industries. IZA Discussion Papers.

Bhaumik, S.K.; Driffield, N.; Pal, S., (2010). Does Ownership Structure of EmergingMarket Firms Affect their Outward FDI? The Case of the Indian Automotive and Pharmaceutical Sectors, Journal of International Business Studies, 41(3), 437-450.

Blomqvist, K., Hurmelinna-Laukkanen, P., Nummela, N., \& Saarenketo, S. (2008). The role of trust and contracts in the internationalization of technology- 
intensive Born Globals. Journal of Engineering and Technology Management, 25(1), 123-135.

Blonigen, B. A., \& Wang, M. (2004). Inappropriate pooling of wealthy and poor countries in empirical FDI studies. National Bureau of Economic Research.

Brewster, C., Mayne, L., \& Tregaskis, O. (1997). Flexible working in Europe: A review of the evidence. Management International Review, 37(1), 85-103.

Chetty, S. K., \& Wilson, H. I. M. (2003). Collaborating with competitors to acquire resources. International Business Review, 12(1), 61-81.

Contractor, F. J., Hsu, C.-C., \& Kundu, S. K. (2005). Explaining export performance: a comparative study of international new ventures in Indian and Taiwanese software industry. Management International Review, 45(1), 83-110.

Coviello, N. E., \& Cox, M. P. (2006). The resource dynamics of international new venture networks. Journal of International Entrepreneurship, 4(2/3), 113-132.

Daghfous, A., Belkhodja, O., \& Angell, L. C. (2013). Understanding and managing knowledge loss. Journal of Knowledge Management, 17(5), 639-660.

Das, S. (1995). Size, age and firm growth in an infant industry: The computer hardware industry in India. International Journal of Industrial Organization, 13(1), 111-126.

De Cuyper, N., \& De Witte, H. (2007). Job insecurity in temporary versus permanent workers: Associations with attitudes, well-being, and behaviour. Work \& Stress, 21(1), 65-84.

Dimaggio, P., \& Powell, W. (1983). The Iron Cage Revisited - Institutional Isomorphism And Collective Rationality In Organisational Fields. In W. Powell, \& P. Dimaggio (Eds.), The New Institutionalism In Organisational Analysis (pp. 63-82). Chicago: Chicago University Press.

Durst, S., \& Wilhelm, S. (2011). Knowledge management in practice: insights into a medium - sized enterprise's exposure to knowledge loss. Prometheus, 29(1), 23-38.

Edwards, T., P. Edwards., A. Ferner., P. Marginson and O. Tregaskis (2010). 'Multinational Companies and the Diffusion of Employment Practices from Outside the Country of Origin Explaining Variation Across Firms', Management International Review, 50(5), 613-634.

Efrat, K., \& Shoham, A. (2011). Environmental characteristics and technological capabilities' interaction in high-technology born global firms. European Journal of International Management, 5(3), 271-284.

Efrat, K., \& Shoham, A. (2012). Born global firms: The differences between their short-and long-term performance drivers. Journal of World Business, 47(4), 675-685.

Enterprise Surveys. The World Bank. http://www.enterprisesurveys.org. Accessed 14 December 2012.

Evangelista, F. (2005). Qualitative insights into the international new venture creation process. Journal of International Entrepreneurship, 3(3), 179-198.

Evans, D. S. (1987). The relationship between firm growth, size, and age: Estimates for 100 manufacturing industries. The Journal of Industrial Economics, 35(4), 567-581.

Evers, N., Andersson, S., \& Hannibal, M. (2012). Stakeholders and Marketing Capabilities in International New Ventures: Evidence from Ireland, Sweden and Denmark. Journal of International Marketing, 20(4), 46-71. 
Fernhaber, S. A., Mcdougall-Covin, P. P., \& Shepherd, D. A. (2009). International entrepreneurship: leveraging internal and external knowledge sources. Strategic Entrepreneurship Journal, 3(4), 297-320.

Fong, C.-Y., Ooi, K.-B., Tan, B.-I., Lee, V.-H., \& Chong, A. Y.-L. (2011). HRM practices and knowledge sharing: an empirical study. International Journal of Manpower, 32(5/6), 704-723.

Freeman, S., Edwards, R., \& Schroder, B. (2006). How smaller born-global firms use networks and alliances to overcome constraints to rapid internationalization. Journal of International Marketing, 14(3), 33-63.

Freeman, S., Hutchings, K., \& Chetty, S. (2012). Born-Globals and Culturally Proximate Markets. Management International Review, 52(3), 425-460.

Freeman, S., Hutchings, K., Lazaris, M., \& Zyngier, S. (2010). A model of rapid knowledge development: The smaller born-global firm. International Business Review, 19(1), 70-84.

Gabrielsson, M., \& Gabrielsson, P. (2011). Internet-based sales channel strategies of born global firms. International Business Review, 20(1), 88-99.

Gabrielsson, M., \& Kirpalani, V. (2004). Born globals: how to reach new business space rapidly. International business review, 13(5), 555-571.

Gabrielsson, M., Kirpalani, V., Dimitratos, P., Solberg, C. A., \& Zucchella, A. (2008). Born globals: Propositions to help advance the theory. International Business Review, 17(4), 385-401.

Gabrielsson, M., Sasi, V., \& Darling, J. (2004). Finance strategies of rapidly-growing Finnish SMEs: born internationals and born globals. European Business Review, 16(6), 590-604.

Gassmann, O., \& Keupp, M. M. (2007). The competitive advantage of early and rapidly internationalising SMEs in the biotechnology industry: A knowledgebased view. Journal of World Business, 42(3), 350-366.

Gilbert, B. A., McDougall, P. P., \& Audretsch, D. B. (2006). New Venture Growth: A Review and Extension. Journal of Management, 32(6), 926-950.

Gooderham, P. N., Nordhaug, O., \& Ringdal, K. (1999). Institutional and rational determinants of organizational practices: human resource management in European firms. Administrative Science Quarterly, 44(3), 507-531.

Grant, R. M. (1996). Prospering in dynamically-competitive environments: organizational capability as knowledge integration. Organization Science, 7(4), 375-387.

Hashai, N. (2011). Sequencing the expansion of geographic scope and foreign operations by "born global" firms. Journal of International Business Studies, 42(8), 995-1015.

Hashai, N., \& Almor, T. (2004). Gradually internationalizing 'born global'firms: an oxymoron? International business review, 13(4), 465-483.

Hewerdine, L., \& Welch, C. (2013). Are international new ventures really new? A process study of organizational emergence and internationalization. Journal of World Business, 48(4), 466-477.

Hite, M., \& Hesterly, W. S. (2001). The evolution of firm networks: From emergence to early growth of the firm. Strategic Management Journal, 22(3), 275-286.

Holtbrügge, D., Friedmann, C. B., \& Puck, J. F. (2010). Recruitment and retention in foreign firms in India: A resource - based view. Human Resource Management, 49(3), 439-455. 
Hoskisson, R. E., Wright, M., Filatotchev, I., \& Peng, M. W. (2013). Emerging Multinationals from Mid - Range Economies: The Influence of Institutions and Factor Markets. Journal of Management Studies, 50(7), 1295 - 1321.

Hsu, Y.-R., \& Leat, M. (2000). A study of HRM and recruitment and selection policies and practices in Taiwan. International Journal of Human Resource Management, 11(2), 413-435.

Jensen, N. M., Li, Q., \& Rahman, A. (2010). Understanding corruption and firm responses in cross-national firm-level surveys. Journal of International Business Studies, 41(9), 1481-1504.

Jiménez-Jiménez, D., \& Sanz-Valle, R. (2005). Innovation and human resource management fit: an empirical study. International journal of manpower, 26(4), 364-381.

Joe, C., Yoong, P., \& Patel, K. (2013). Knowledge loss when older experts leave knowledge-intensive organizations. Journal of Knowledge Management, 17(6), 913-927.

Johanson, J., \& Vahlne, J. E. (2006). Commitment and opportunity development in the internationalization process: A note on the Uppsala internationalization process model. Management International Review, 46(2), 165-178.

Jones, M. V. (2001). First steps in internationalisation: Concepts and evidence from a sample of small high-technology firms. Journal of International Management, 7(3), 191-210.

Jormanainen, I., \& Koveshnikov, A. (2012). International Activities of Emerging Market Firms. Management International Review, 52(5), 691-725.

Kalinic, I., \& Forza, C. (2012). Rapid internationalization of traditional SMEs: Between gradualist models and born globals. International Business Review, 21(4), 694-707.

Kalleberg, A. L. (2000). Nonstandard employment relations: Part-time, temporary and contract work. Annual Review of Sociology, 26, 341-365.

Kang, S.-C., Morris, S. S., \& Snell, S. A. (2007). Relational archetypes, organizational learning, and value creation: Extending the human resource architecture. Academy of Management Review, 32(1), 236-256.

Karamessini, M. (2008). Continuity and change in the southern European social model. International Labour Review, 147(1), 43-70.

Karra, N., Phillips, N., \& Tracey, P. (2008). Building the Born Global Firm: Developing Entrepreneurial Capabilities for International New Venture Success. Long Range Planning, 41(4), 440-458.

Khalid, S. A. P., \& Larimo, J. P. (2012). Firm Specific Advantage in Developed Markets Dynamic Capability Perspective. Management International Review, 52(2), 233-250.

Kim, D., Basu, C., Naidu, G., \& Cavusgil, E. (2011). The innovativeness of BornGlobals and customer orientation: learning from Indian born-globals. Journal of Business Research, 64(8), 879-886.

Knight, G. A., \& Cavusgil, S. T. (2004). Innovation, organizational capabilities, and the born-global firm. Journal of International Business Studies, 35(2), 124141.

Knight, G. A., Madsen, T. K., \& Servais, P. (2004). An inquiry into born-global firms in Europe and the USA. International Marketing Review, 21(6), 645-665.

Kogut, B., \& Zander, U. (1992). Knowledge of the firm, combinative capabilities, and the replication of technology. Organization Science, 3(3), 383-397. 
Kuivalainen, O., Sundqvist, S., \& Servais, P. (2007). Firms' degree of bornglobalness, international entrepreneurial orientation and export performance. Journal of World Business, 42(3), 253-267.

Leonard, D. (1998). Wellsprings of knowledge: Building and sustaining the sources of innovation. Boston, MA: Harvard Business Press.

Lepak, D., \& Snell, S. (1999). The Human Resource Architecture: Toward a Theory of Human Capial Allocation and Development. The Academy of Management Review, 24(1), 31-48.

Lepak, D., \& Snell, S. (2008). Employment Subsystems and the 'HR Architecture'. In P. Boxall, J. Purcell, \& P. Wright (Eds.), The Oxford Handbook of Human Resource Management. Oxford: Oxford University Press.

Li, L., Qian, G., \& Qian, Z. (2012). Early internationalization and performance of small high-tech "born-globals". International Marketing Review, 29(5), 536561.

Loane, S., Bell, J. D., \& McNaughton, R. (2007). A cross-national study on the impact of management teams on the rapid internationalization of small firms. Journal of World Business, 42(4), 489-504.

Lu, J, Liu, X, Wang, H (2011) Motives for outward FDI of Chinese private firms: Firm resources, industry dynamics and government policies, Management and Organization Review, 7(2), 223-248

Luo, Y., \& Tung, R. L. (2007). International expansion of emerging market enterprises: A springboard perspective. Journal of International Business Studies, 38(4), 481-498.

Martins, E. C., \& Meyer, H. W. (2012). Organizational and behavioral factors that influence knowledge retention. Journal of Knowledge Management, 16(1), 7796.

Mata, J., \& Portugal, P. (1994). Life Duration of New Firms. Journal of Industrial Economics, 42(3), 227-245.

Mathews, J. A., \& Zander, I. (2007). The international entrepreneurial dynamics of accelerated internationalisation. Journal of International Business Studies, $38(3), 387-403$.

Miles, R. E., \& Snow, C. C. (1984). Designing strategic human resources systems. Organizational Dynamics, Summer, 36-52.

Nonaka, I. (1994). A dynamic theory of organizational knowledge creation. Organization Science, 5(1), 14-37.

Nordman, E. R., \& Melén, S. (2008). The impact of different kinds of knowledge for the internationalization process of born globals in the biotech business. Journal of World Business, 43(2), 171-185.

Odorici, V., \& Presutti, M. (2013). The entrepreneurial experience and strategic orientation of high-tech born global start-ups: An analysis of novice and habitual entrepreneurs. Journal of International Entrepreneurship, 11(3), 268291.

Ojala, A., \& Heikkilä, J. (2011). Entrepreneurship training for new ventures. International Entrepreneurship and Management Journal, 7(3), 297-310.

Park, T., \& Rhee, J. (2012). Antecedents of knowledge competency and performance in born globals: The moderating effects of absorptive capacity. Management Decision, 50(8), 1361-1381.

Presutti, M., Boari, C., \& Fratocchi, L. (2007). Knowledge acquisition and the foreign development of high-tech start-ups: A social capital approach. International Business Review, 16(1), 23-46. 
Quester, P. G., \& Kelly, A. (1999). Internal marketing practices in the Australian financial sector: an exploratory study. Journal of Applied Management Studies, $8(2), 217-229$.

Rasmussen, E., Madsen, T., \& Servais, P. (2012). On the foundation and early development of domestic and international new ventures. Journal of Management \& Governance, 16(4), 543-556.

Rialp, A., Rialp, J., \& Knight, G. A. (2005). The phenomenon of early internationalizing firms: what do we know after a decade (1993-2003) of scientific inquiry? International Business Review, 14(2), 147-166.

Robertson, M., \& Swan, J. (2003). 'Control - What Control?' Culture and Ambiguity Within a Knowledge Intensive Firm. Journal of Management Studies, 40(4), 831-858.

Ryan, A. M., McFarland, L., Baron, H., \& Page, R. (1999). An international look at selection practices: Nation and culture as explanations for variability in practice. Personnel Psychology, 52(2), 359-392.

Sahadev, S., \& Demirbag, M. (2010). A comparative analysis of employment practices among post-communist and capitalist countries in South Eastern Europe. Employee Relations, 32(3), 248-261.

Sahadev, S., \& Demirbag, M. (2011). Exploring variations in employment practices in the emerging economies of Europe: assessing the impact of foreign ownership and European integration. Human Resource Management Journal, 21(4), 395414.

Schuler, R., \& Jackson, S. (1987). Linking Competitive Strategies with Human Resource Management Practices. Academy of Management Executive, 1(3), 207-219.

Schwab, K. (2011). The Global Competitiveness Report 2011-12. Geneva: World Economic Forum.

Sepulveda, F., \& Gabrielsson, M. (2013). Network development and firm growth: A resource-based study of B2B Born Globals. Industrial Marketing Management, 42(5), $792-804$.

Shipton, H., Fay, D., West, M., Patterson, M., \& Birdi, K. (2005). Managing people to promote innovation. Creativity and Innovation Management, 14(2), 118-128.

Smith, A. R., Ryan, P. A., \& Collings, D. G. (2012). Born global networks: the role of connectors. European Journal of International Management, 6(5), 566-589.

Spence, M., Orser, B., \& Riding, A. (2011). A Comparative Study of International and Domestic New Ventures. Management International Review, 51(1), 3-21.

Starbuck, W. H. (1992). Learning by Knowledge Intensive Firms. Journal of Management Studies, 29(6), 713-740.

Subramaniam, M., \& Youndt, M. A. (2005). The influence of intellectual capital on the types of innovative capabilities. Academy of Management Journal, 48(3), 450-463.

Swart, J. (2008). HRM and Knowledge Workers. In P. Boxall, J. Purcell, \& C. Wright (Eds.), The Oxford Handbook of Human Resource Management. Oxford: Oxford University Press.

Swart, J., \& Harvey, P. (2011). Identifying knowledge boundaries: the case of networked projects. Journal of Knowledge Management, 15(5), 703-721.

Swart, J., \& Kinnie, N. (2003a). Knowledge-intensive firms: the influence of the client on HR systems. Human Resource Management Journal, 13(3), 37-55.

Swart, J., \& Kinnie, N. (2003b). Sharing knowledge in knowledge-intensive firms. Human Resource Management Journal, 13(2), 60-75. 
Taylor, M., \& Jack, R. (2013). Understanding the pace, scale and pattern of firm internationalization: An extension of the'born global'concept. International Small Business Journal, 31(6), 701-721.

Thite, M., Wilkinson, A., \& Shah, D. (2012). Internationalization and HRM strategies across subsidiaries in multinational corporations from emerging economies: A conceptual framework. Journal of World Business, 47(2), 251-258.

Tregaskis, O., \& Brewster, C. (2006). Converging or diverging? A comparative analysis of trends in contingent employment practice in Europe over a decade. Journal of International Business Studies, 37(1), 111-126.

Uner, M. M., Kocak, A., Cavusgil, E., \& Cavusgil, S. T. (2013). Do barriers to export vary for born globals and across stages of internationalization? An empirical inquiry in the emerging market of Turkey. International Business Review, 22(5), 800-813.

Vasilchenko, E., \& Morrish, S. (2011). The Role of Entrepreneurial Networks in the Exploration and Exploitation of Internationalization Opportunities by Information and Communication Technology Firms. [Case Study]. Journal of International Marketing, 19(4), 88-105.

Weerawardena, J., Mort, G. S., Liesch, P. W., \& Knight, G. (2007). Conceptualizing accelerated internationalization in the born global firm: A dynamic capabilities perspective. Journal of World Business, 42(3), 294-306.

Wickramasekera, R., \& Oczkowski, E. (2006). Stage models re-visited: A measure of the stage of internationalisation of a firm. Management International Review, 46(1), 39-55.

Wright, P. M., Dunford, B. B., \& Snell, S. A. (2001). Human resources and the resource based view of the firm. Journal of Management, 27(6), 701-721.

Zhang, J., \& Dai, X. (2013). Research on Chinese Born Global Firms' International Entrepreneurial Mechanism and Development Mode. International Business and Management, 7(1), 78-84.

Zhang, M., Sarker, S., \& Sarker, S. (2013). Drivers and export performance impacts of IT capability in 'born - global' firms: a cross - national study. Information Systems Journal, 23(5), 419-443.

Zhou, Y., Hong, Y., \& Liu, J. (2013). Internal Commitment or External Collaboration? The Impact of Human Resource Management Systems on Firm Innovation and Performance. Human Resource Management, 52(2), 263-288.

Zou, H., \& Ghauri, P. N. (2010). Internationalizing by learning: the case of Chinese high-tech new ventures. International Marketing Review, 27(2), 223-244. 
Table.1 Sample Profile of Firms

\begin{tabular}{|c|c|c|}
\hline $\begin{array}{l}\text { Country only without } \\
\text { survey data }\end{array}$ & $\begin{array}{l}\text { Mean age of firms from the } \\
\text { country (yrs) }\end{array}$ & $\begin{array}{l}\text { No. of firms } \\
\text { selected from the } \\
\text { county }\end{array}$ \\
\hline Argentina & 18.53 & 47 \\
\hline Bolivia & 20.88 & 16 \\
\hline Brazil & 20.68 & 28 \\
\hline Bulgaria & 12.71 & 28 \\
\hline Chile & 20.54 & 54 \\
\hline Colombia & 18.61 & 41 \\
\hline Costarica & 24.18 & 17 \\
\hline Croatia & 16.11 & 19 \\
\hline Czech Republic & 14.59 & 22 \\
\hline Ecuador & 20.19 & 16 \\
\hline ElSalvador & 21.90 & 49 \\
\hline Estonia & 15.00 & 22 \\
\hline Guatemala & 19.85 & 41 \\
\hline Honduras & 19.13 & 15 \\
\hline Indonesia & 18.32 & 28 \\
\hline Kenya & 19.08 & 12 \\
\hline Latvia & 14.80 & 15 \\
\hline Lithuania & 13.83 & 6 \\
\hline Mexico & 18.69 & 61 \\
\hline Paraguay & 16.80 & 15 \\
\hline Peru & 18.32 & 76 \\
\hline Philippines & 17.55 & 86 \\
\hline Russia & 13.53 & 15 \\
\hline
\end{tabular}




\begin{tabular}{|l|l|l|}
\hline Slovenia & 15.07 & 14 \\
\hline SouthAfrica & 21.35 & 23 \\
\hline Turkey & 18.09 & 55 \\
\hline Ukraine & 14.82 & 11 \\
\hline Uruguay & 23.38 & 21 \\
\hline Vietnam & 15.24 & 37 \\
\hline Total & 18.35 & 890 \\
\hline
\end{tabular}


Table 2 correlation coefficient between variables considered in the model

\begin{tabular}{|c|c|c|c|c|c|c|c|c|c|c|c|c|c|c|c|c|c|c|c|}
\hline & 1 & 2 & 3 & 4 & 5 & 6 & 7 & 8 & 9 & 10 & 11 & 12 & 13 & 14 & 15 & 16 & 17 & 18 & 19 \\
\hline Infrastructure & 1 & 0.6 & -.008 & .04 & -0.082 & .043 & 0.144 & -0.235 & -.013 & -0.092 & -.049 & -.042 & .132 & -0.09 & -.045 & -0.143 & -0.223 & .023 & $\begin{array}{l}- \\
0.1 \\
76\end{array}$ \\
\hline Institutional & & 1 & .059 & .04 & -0.1 & 0.117 & -0.068 & -0.109 & .025 & -.022 & -.001 & -.014 & .100 & -0.101 & -.064 & .010 & -.057 & -.017 & $\begin{array}{l}- \\
.01 \\
9\end{array}$ \\
\hline $\begin{array}{l}\text { Age of the } \\
\text { firm }\end{array}$ & & & 1 & .02 & -0.071 & .049 & -.031 & -.019 & 0.086 & .008 & -.017 & .038 & -.005 & -.003 & -.059 & -.015 & .060 & .046 & $\begin{array}{l}- \\
.00 \\
6\end{array}$ \\
\hline $\begin{array}{l}\text { Textiles } \quad \& \\
\text { Leather }\end{array}$ & & & & 1 & -0.127 & -0.159 & -0.149 & -0.086 & -0.112 & -.042 & -0.11 & -.032 & -.118 & -.016 & .018 & .040 & -0.066 & .018 & $\begin{array}{l}- \\
0.0 \\
84\end{array}$ \\
\hline Garments & & & & & 1 & -0.184 & -0.173 & -0.099 & -0.129 & -.048 & -0.128 & -.037 & -.136 & -.041 & 0.096 & 0.18 & -.019 & .035 & $\begin{array}{l}- \\
0.1 \\
0.1\end{array}$ \\
\hline Food & & & & & & 1 & -0.216 & -0.124 & -0.162 & -.061 & -0.16 & -.046 & -.170 & -.077 & -0.216 & .065 & 0.258 & .006 & $\begin{array}{l}- \\
.03 \\
6\end{array}$ \\
\hline $\begin{array}{l}\text { Metals } \\
\text { \&Machinery }\end{array}$ & & & & & & & 1 & -0.117 & -0.152 & -.057 & -0.15 & -.043 & -.160 & -.023 & .085 & -0.15 & -.044 & -.002 & $\begin{array}{l}.01 \\
4\end{array}$ \\
\hline Electronics & & & & & & & & 1 & -0.087 & -.033 & -0.086 & -.025 & -.092 & 0.161 & 0.128 & 0.176 & .022 & $\begin{array}{l}0.09 \\
4 \\
\end{array}$ & $\begin{array}{l}0.2 \\
14 \\
\end{array}$ \\
\hline $\begin{array}{l}\text { Chemicals\& } \\
\text { pharmaceutical } \\
\text { s }\end{array}$ & & & & & & & & & 1 & -.043 & -0.112 & -.032 & -.120 & .061 & -0.094 & -0.172 & -.035 & -.082 & $\begin{array}{l}0.0 \\
89\end{array}$ \\
\hline $\begin{array}{l}\text { Wood } \quad \& \\
\text { furniture }\end{array}$ & & & & & & & & & & 1 & -.042 & -.012 & -.045 & -.016 & .026 & .073 & .035 & -.014 & $\begin{array}{l}- \\
.05 \\
6\end{array}$ \\
\hline $\begin{array}{lr}\text { Non- } & \text { Metallic } \\
\& & \text { plastic }\end{array}$ & & & & & & & & & & & 1 & -.032 & -.119 & .058 & .003 & -.078 & $-.076^{*}$ & -.007 & $\begin{array}{l}.04 \\
2 \\
\end{array}$ \\
\hline
\end{tabular}




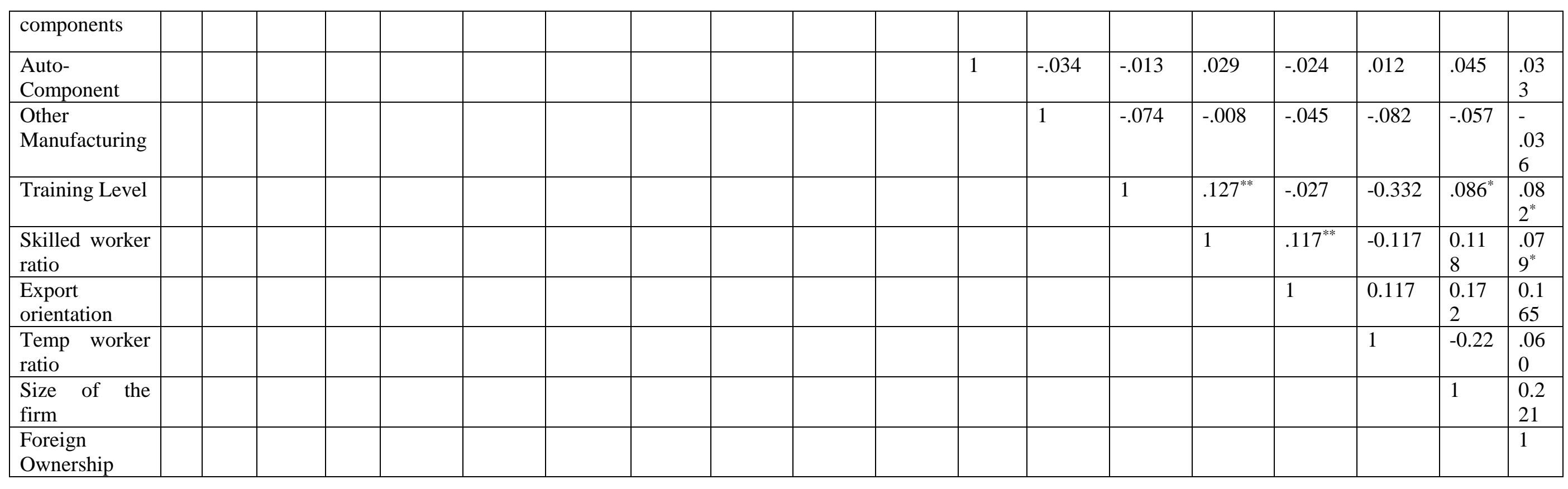


Table.3 Regression analysis for temporary worker ratio

\begin{tabular}{|l|l|l|l|}
\hline & $\begin{array}{l}\text { Standardized } \\
\text { Coefficient }\end{array}$ & t-Value & Significance \\
\hline (Constant) & & 5.667 & .000 \\
\hline Size of the Firm & -.254 & -7.962 & .000 \\
\hline Export Orientation & .097 & 2.917 & .004 \\
\hline Foreign investment level & .067 & 2.003 & .045 \\
\hline Age of the firm & .052 & 1.705 & .089 \\
\hline Infrastructural Development & -.250 & -5.868 & .000 \\
\hline Institutional Development & .067 & 1.643 & .101 \\
\hline Textiles/Leather & .133 & 1.705 & .089 \\
\hline Garments & .175 & 2.046 & .041 \\
\hline Food & .444 & 4.511 & .000 \\
\hline Metals and Machinery & .236 & 2.472 & .014 \\
\hline Electronics & .114 & 1.712 & .087 \\
\hline Chemicals and pharmaceuticals & .135 & 1.700 & .090 \\
\hline Wood/furniture & .106 & 1.920 & .055 \\
\hline Non-Metallic and Plastic Components & .069 & 1.354 & .176 \\
\hline Auto Components & .824 & .068 \\
\hline Other Manufacturing & .095 \\
\hline
\end{tabular}

$\mathrm{R}^{2}=0.201 ;$ Adj. $\mathrm{R}^{2}=0.187 ; \mathrm{F}=13.7(\mathrm{p}<0.00)$ 
Table.4 Regression Analysis for Skill-worker Ratio

\begin{tabular}{|l|l|l|l|}
\hline & $\begin{array}{l}\text { Standardized } \\
\text { Coefficient }\end{array}$ & $\mathrm{t}$-Value & Significance \\
\hline (Constant) & & 5.109 & .000 \\
\hline Size of the Firm & .080 & 2.358 & .019 \\
\hline Export Orientation & .080 & 2.268 & .024 \\
\hline Foreign investment level & .041 & 1.161 & .246 \\
\hline Age of the firm & -.033 & -1.016 & .310 \\
\hline Infrastructural Development & .014 & .303 & .762 \\
\hline Institutional Development & -.022 & -.499 & .618 \\
\hline Textiles/Leather & -.128 & -1.544 & .123 \\
\hline Garments & -.091 & -.999 & .318 \\
\hline Food & -.364 & -3.477 & .001 \\
\hline Metals and Machinery & -.103 & -1.022 & .307 \\
\hline Electronics & -.026 &.- .364 & .716 \\
\hline Chemicals and pharmaceuticals & -.212 & -2.513 & .012 \\
\hline Wood/furniture & -.035 &.- .779 & .436 \\
\hline Non-Metallic and Plastic Components & -.018 & -1.645 & .100 \\
\hline Auto Components & -.150 & -.456 & .648 \\
\hline Other Manufacturing & & .084 \\
\hline R2 = & & & \\
\hline
\end{tabular}

$\mathrm{R}^{2}=0.099 ; \quad$ Adj $\mathrm{R}^{2}=0.083 ; \mathrm{F}=6.016(\mathrm{p}<0.00)$ 
Table.5 Regression Analysis for Training Level

\begin{tabular}{|l|l|l|l|}
\hline & $\begin{array}{l}\text { Standardized } \\
\text { Coefficient }\end{array}$ & T-value & significance \\
\hline (Constant) & & 6.126 & .000 \\
\hline Size of the Firm & .076 & 2.206 & .028 \\
\hline Export orientation & -.052 & -1.452 & .147 \\
\hline Foreign Investment Level & .032 & .896 & .370 \\
\hline Age of the Firm & .002 & .051 & .960 \\
\hline Infrastructure Development & .004 & .077 & .939 \\
\hline Institutional Development & -.078 & -1.767 & .078 \\
\hline Textiles/leather & -.178 & -2.113 & .035 \\
\hline Garments & -.222 & -2.391 & .017 \\
\hline Food & -.273 & -2.558 & .011 \\
\hline Metals and Machinery & -.243 & -2.350 & .019 \\
\hline Electronics & .001 & .018 & .985 \\
\hline Chemicals and Pharmaceuticals & -.121 & -1.402 & .161 \\
\hline Wood/Furniture & -.081 & -1.751 & .080 \\
\hline Non-Metallic and Plastic Components & -.122 & -1.443 & .149 \\
\hline Auto Components & -.073 & -1.771 & .077 \\
\hline Other Manufacturing & -.236 & -2.651 & .008 \\
\hline & & & \\
\hline
\end{tabular}

$\mathrm{R}^{2}=0.062 ;$ Adj. $\mathrm{R}^{2}=0.045 ; \mathrm{F}=3.63(\mathrm{p}<0.00)$ 